\title{
CHARACTERIZATION AND DIVERSITY OF MACROINVERTEBRATES OF THE BOUHAMDANE STREAM (NORTHEAST OF ALGERIA)
}

\author{
Abdelhakim Rouibi ${ }^{a}$, Affef Baaloudj ${ }^{*}$, Faycal Chahrour ${ }^{b}$, Ahmed Kerfouf $^{c}$, Hadia Rizi $^{\mathrm{d}}$, Rafik Berdja ${ }^{\mathrm{e}}$, Wi- \\ dad Belkhiria, Sara Chaib ${ }^{a}$ and Meriem Gharbi ${ }^{\mathrm{a}}$
}

\begin{abstract}
a'Laboratoire Biologie, Eau et Environnement (LBEE), Faculté SNV-STU, Université 8 Mai 1945 Guelma. BP. 40124000 Guelma, Algérie; 'Laboratoire Réseau de Surveillance Environnementale (LRSE), Université Ahmed Ben Bella, Oran1, Algeria; ${ }^{\mathrm{c}}$ Laboratory of Eco-development of Spaces, University of Djillali Liabes, Sidi Bel Abbes, 22000, Algeria; ${ }^{\mathrm{d}}$ University Chadli Bendjedid d'ElTarf, 36000, Algeria; 'Laboratory of Improvement of the Phytosanitary Protection Techniques in Mountainous Agrosystems, Agronomy Department (LATPPAM), ISVSA, Batna 1 University, Batna 05000, Algeria *Corresponding author. Email: bafef@yahoo.fr; baaloudj.affef@univ-guelma.dz
\end{abstract}

\author{
Article history \\ Received: 15 December 2020; \\ accepted 9 April 2021
}

\section{Keywords:}

Macroinvertebrates;

biodiversity; aquatic

environment; Bouhamdane

Stream; northeast Algeria

\begin{abstract}
Freshwaters are among the most threatened ecosystems, particularly in North Africa where urbanization and climate change are exerting an important pressure on aquatic fauna. Longterm investigation of macroinvertebrates is one of the best ways of tracking and understanding the influence of environmental and anthropogenic pressures on community dynamics. In this study, we focus on determining the community structure and diversity of benthic macroinvertebrates as well as the state of aquatic physicochemical parameters in the Bouhamdane Stream, near the outlet of Bouhamdane dam, Seybouse watershed, north-eastern Algeria. We carried out a bi-monthly sampling of macroinvertebrates and nine water physicochemical parameters from September 2017 to July 2018 at three sites. Results show that the collected macroinvertebrates (6756 individuals) belong to 15 families and 12 orders. The abundance of the macrofauna consisted of $88.19 \%$ crustaceans, $7.74 \%$ insects, $3.7 \%$ molluses and $0.16 \%$ annelids. Physicochemical analyzes (depth, turbidity, $\mathrm{pH}$, dissolved O2, temperature, salinity, and conductivity) showed variability among sites. The families of Gammaridae and Baetidae were the most frequent and the most abundant on all the stations. The results indicate that aquatic macroinvertebrates constitute good indicators of the biological quality of water. This study shows that even with the occurrence of regular dam water discharge, the macroinvertebrate community is still able to persist either through adaptation to high water velocity or high colonization rate.
\end{abstract}

\section{INTRODUCTION}

Since the 19th century, watercourses, particularly in industrialized countries, have been seriously affected by different types of pollution (industrial, urban and agricultural). In several countries, programmes for monitoring the biological integrity of watercourses have been used to assess the quality of surface water and the health condition of aquatic ecosystems (Giudicelli et al. 1985; Dajoz 2006). These programmes primarily use benthic macroinvertebrate communities as biological indicators. Besides pollution, climate change has affected aquatic communities globally, particularly in hot and dry environments (Dudgeon et al. 2006; Boix et al. 2010; García et al. 2010).

Mediterranean rivers are characterized by irregular hydrological flows and sudden fluctuations (Engelhardt 1998; Fustec and Lefeuvre 2000). In North Africa, freshwater is relatively scarce and most rivers are restricted to the littoral region (Fleurant 2016). As a result, the majority of human population lives in this area, which increases the anthropogenic pollution (e.g. agriculture, industry, sewage). This pollution affects various abiotic and biotic factors of the aquatic habitat and ultimately changes the population dynamics and community structure of fauna and flora (Ramade et al. 1994; Ferguani and Arab 2013; Alhou et al. 2014). Invertebrates are the dominant organisms in aquatic ecosystems in terms of biomass, playing a crucial role of predator and prey in the foodweb (Véronique 2014). They are excellent bioindicators of the ecological integrity of natural habitats due to their great diversity and sensitivity to pollution and habitat degradation (Bournaud et al. 1980; Chessman 1995; Barbour et al. 1999; Sanogo et al. 2014). Consequently, anthropogenic activities, including laundry, dishes, agriculture and deforestation observed in the sampling sites make it possible to differentiate the richness and abundance of aquatic macroinvertebrates depending on the site (Chessman 1995; Camargo et al. 2004; Armellin 2010). Thus, their monitoring is essential to understand the ecological state of the freshwater ecosystem and manage biodiversity (Dudgeon et al. 2006).

The study of the macrobenthic fauna of rivers in Algeria has been undertaken in recent decades in order to draw 
up an inventory as exhaustive as possible and to have knowledge of their systematics, ecology, and biogeography (Haouchine 2011). In northeast Algeria, studies on macroinvertebrates peaked in the last decade (Zerguine and Rossaro 2010; Zebsa et al. 2014 a, b; Khelifa et al. 2016; Khelifa 2019; Baaloudj et al. 2020), revealing an important biodiversity and endemism. The objective of this study is to characterize the structure and diversity of benthic macroinvertebrates of an understudied watercourse, Bouhamdane Stream in northeast Algeria. We specifically studied their distribution, abundance and diversity using field monitoring in three sites between September 2017 and July 2018.

\section{MATERIALS AND METHODS}

\section{Description of the study site}

The Bouhamdane Stream is one of the two most important tributaries of the Seybouse River located in the northeast Algeria (36 $27^{\prime} 46^{\prime \prime N}, 7^{\circ} 6^{\prime} 40^{\prime}$ ” E) (Figure 1). The length of the river is $37.5 \mathrm{~km}$ and the elevation varies from $\sim 250$ to $550 \mathrm{~m}$. This stream emerges from the confluence of Sabath and Zenati streams (Table 1). Vegetation mainly includes: Juncus sp., Typha sp., Phragmites australis, Tamarix sp., Nerium oleander, and Lemna minor. The regional climate is typically

Table 1. Geographical coordinates of sites and sampling dates.

\begin{tabular}{|c|c|}
\hline Sites & Geographical coordinates \\
\hline 1 & $36^{\circ} 27.032^{\prime} \mathrm{N}, 7^{\circ} 6.084^{\prime} \mathrm{E}$ \\
\hline 2 & $36^{\circ} 27.318^{\prime} \mathrm{N}, 7^{\circ} 6.334^{\prime} \mathrm{E}$ \\
\hline 3 & $36^{\circ} 28.148^{\prime} \mathrm{N}, 7^{\circ} 7.225^{\prime} \mathrm{E}$ \\
\hline
\end{tabular}

Mediterranean with a long hot and dry season (8 months) and a short wet season (4 months).

\section{Measurements and sampling}

Samples were taken at each site twice per month from September 2017 to July 2018, resulting in a total of 22 samples per site (from 2 September 2017 until 18 July 2018). The physicochemical parameters such as temperature, conductivity, $\mathrm{O} 2, \mathrm{pH}$, salinity were measured in situ between 8 and 12 in the morning using a multi-parameter (Multi 197i WTW) and a depth gauge prior to the macroinvertebrate sampling to avoid any disturbance of the environment that could bias the results. Depth was measured at the centre of the bed at the sampling location with a gridded stick. From upstream to downstream, three sites were chosen for the study, depending on the permanence of water and accessibility in all seasons (Table 1). The sites were adjacent and the distance between one site and another was $500 \mathrm{~m}$. We standardized the effort of sampling by limiting the time spent $(3 \mathrm{~h})$ in each site and the number of water sweeps. Macroinvertebrates were sampled in the banks using $100 \mu \mathrm{m}$ mesh dip nets by carrying out ten sweeps following the protocol of the IBGN standard (Archaimbault and Dumont 2010). The collected samples were poured onto a $500 \mu \mathrm{m}$ sieve of mesh for pre-sorting by separating various materials and collecting the specimens using an entomological forceps (Afnor 2010). The collected organisms were fixed in formaldehyde (10\%) in labelled jars (by date and site name) and transported to the laboratory for final analyses. In the laboratory, samples were rinsed thoroughly on a series of sieves of decreasing size ( 5 to $0.2 \mu \mathrm{m}$ ) in order to eliminate as much as possible the remaining fine substrate and

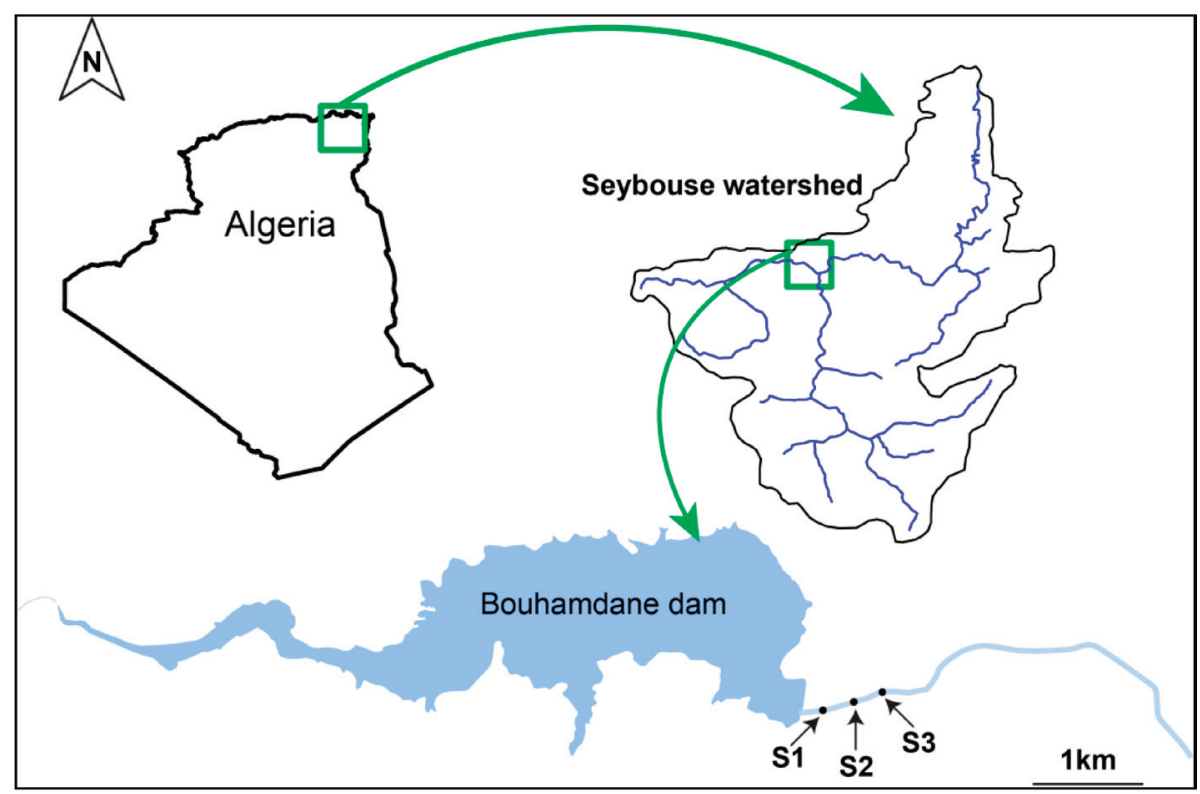

Figure 1. Study area. 
coarse elements (MDDP 2008). Sample identification was carried out using a binocular microscope (Leica DM2500) and various identification keys (Leraut 2007; Tachet 2010, 2013; Moisan 2010).

\section{Data analysis}

All statistical analyzes and the Shannon diversity and equity indices were performed with R 3.5.2 (R Development Core Team 2019) provided with the FactoMineR package. Data were expressed as mean $\pm \mathrm{SD}$. A probability level $<0.05$ was considered significant. The difference across sites of taxonomic richness, abundance, diversity indices and physicochemical parameters was assessed with the Kruskal-Wallis test at a 5\% threshold.

The Canonical Correspondence Analysis (CCA) was performed using Past software version 3 (Hammer et al. 2001) to explore the relationships that may exist between biotic data and abiotic data obtained during sampling.

\section{RESULTS AND DISCUSSION}

\section{Physicochemical quality of water}

Table 2 shows the average values of six physicochemical parameters of water quality in the study sites. In general, the parameter values were very similar among sites. The Kruskal-Wallis tests did not reveal any significant difference in the physicochemical characteristics between the three sites $(p>0.05)$.

\section{Population and spatial structure of benthic macroin- vertebrates}

A total of 6756 specimens were collected during the study period. Our taxonomic analysis showed that the community encompassed three major phyla: Annelida, Arthropoda, and Mollusca. This aquatic fauna was dominated by crustaceans $(88.19 \%)$ followed by insects $(7.74 \%)$. The least prevalent taxa were annelids, molluscs, and nematodes (Figure 2).

Insects were the most taxonomically diverse, comprising seven orders and nine families. We found that most insect individuals sampled belonged to Ephemeroptera $(88.66 \%)$. Diptera occupied the second place with $6.43 \%$, followed by Heteroptera $(3.22 \%)$ and Odonata

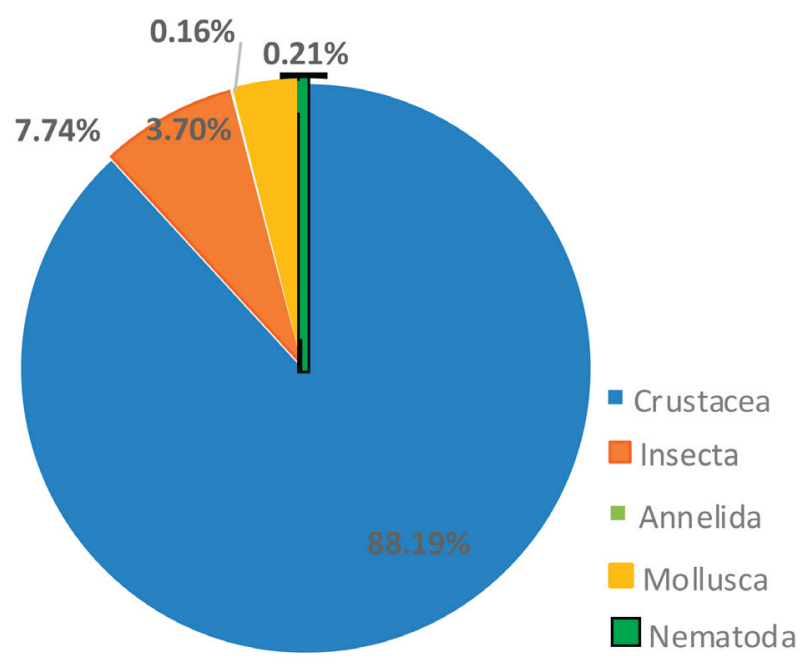

Figure 2. Community composition of sampled macroinvertebrates.

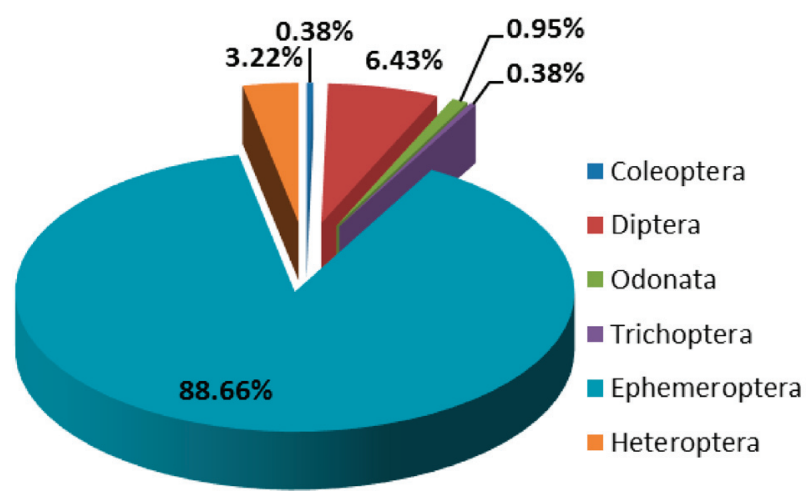

Figure 3. Community composition of the sampled insects based on taxonomic order.

$(0.95 \%)$. Trichoptera and Coleoptera were present at very low abundance $(0.38 \%)$ (Figure 3 ).

Table 3 reveals that crustaceans had the highest abundance among the collected macroinvertebrates with 5958 individuals. Ephemeroptera was the most important order in terms of insect abundance (399 individuals). Also, the families whose frequency of occurrence is equal to 100 are the most pollution tolerant, such as the Chironomidae.

The highest total abundance was recorded at site 2 (2502 individuals) and lowest at site 3 (2039 individuals) (Figure 4). Site 1 recorded the highest taxonomic richness (11 families), while the lowest taxonomic richness was noted in site 3 ( 8 families).

Table 2. Physicochemical characteristics of water from the Bouhamdane Stream.

\begin{tabular}{|l|c|c|c|c|c|c|}
\hline \multicolumn{1}{|c|}{ Parameters } & Depth $(\mathrm{cm})$ & $\mathrm{pH}$ & $\mathrm{T}\left(\mathrm{C}^{\circ}\right)$ & Conductivity $(\mathrm{us} / \mathrm{cm})$ & Salinity $(\mathrm{g} / \mathrm{l})$ & $\mathrm{O}_{2}(\mathrm{mg} / \mathrm{l})$ \\
\hline Sites & $49.08 \pm 8.60$ & $8.28 \pm 0.49$ & $18.36 \pm 3.54$ & $1028.66 \pm 279.28$ & $0.28 \pm 0.16$ & $6.25 \pm 2.18$ \\
\hline Site 1 & $31.1 \pm 15.41$ & $8.50 \pm 0.43$ & $19.12 \pm 3.20$ & $824.4 \pm 69.05$ & $0.15 \pm 0.13$ & $6.88 \pm 1.91$ \\
\hline Site 2 & $38 \pm 20.64$ & $8.44 \pm 0.48$ & $19.44 \pm 2.81$ & $819.22 \pm 92.56$ & $0.22 \pm 0.08$ & $7.18 \pm 1.49$ \\
\hline Site 3 &
\end{tabular}


Table 3. Taxonomic richness, abundance and frequency of occurrence of different collected macroinvertebrate taxa from the Bouhamdane River.

\begin{tabular}{|l|l|l|l|c|c|}
\hline Phylum & Class & Order & Family & Abundance & Frequency of occurrence (\%) \\
\hline Arthropods & Crustacea & Amphipoda & Gammaridae & 5880 & 75 \\
\hline & & Decapoda & Atyidae & 78 & 50 \\
\hline & Insecta & Coleoptera & Gyrinidae & 2 & 25 \\
\hline & & Diptera & Chironomidae & 32 & 25 \\
\hline & & & Ceratopogonidae & 2 & 50 \\
\hline & & Odonata & Libellulidae & 5 & 25 \\
\hline & & Trichoptera & Hydropsychidae & 2 & 75 \\
\hline & & Ephemeroptera & Baetidae & 399 & 75 \\
\hline & & & Caenidae & 70 & 25 \\
\hline Annelida & Clitellata & Arhynchobdellida & Hirudinea & 5 & 25 \\
\hline \multirow{2}{*}{ Mollusca } & Gastropoda & Hygrophila & Lymnaeidae & 11 & 75 \\
\cline { 2 - 6 } & Bivalvia & Sphaeriida & Sphaeriidae & 216 & 25 \\
\hline Nematoda & Enoplea & Mermithida & Mermithidae & 14 & 25 \\
\hline
\end{tabular}

Amphipoda were the most abundant in all study sites (Figure 5). Ephemeroptera was also numerous, followed by Gastropoda. The least abundant were Coleoptera and Trichoptera.

Figure 6 shows the spatial variation of Shannon diversity and equity indices. It indicates that Shannon diversity index decreases overall from upstream to downstream sites. Indeed, the maximum value of the Shannon index is observed at site 1 (1.02), while the minimum value is observed at site 3 (0.64). Likewise, the equity index describes an evolution similar to the Shannon index. Analysis of indices subjected to the Kruskal-Wallis test does not reveal any significant difference between sites $(p>0.05)$.

\section{Relations between macroinvertebrates and the envi- ronment}

The Canonical Correspondence Analysis (CCA) has shown that environmental variables had some influence on the distribution of macroinvertebrates (Figure 7). Axes 1 and 2 explained $78.45 \%$ and $21.55 \%$ of the total

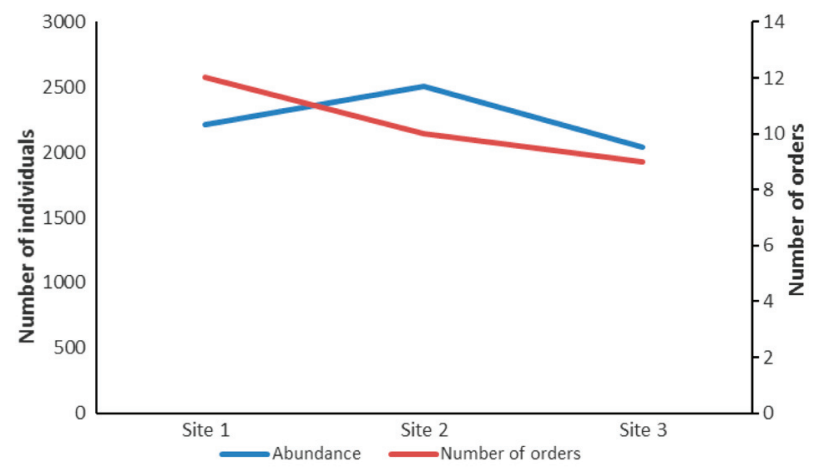

Figure 4. Spatial variation of total abundance and number of orders of macroinvertebrates from the Bouhamdane Stream. variability, respectively. The first axis is positively and strongly correlated with dissolved oxygen, while the second axis is positively correlated with depth. Thus,

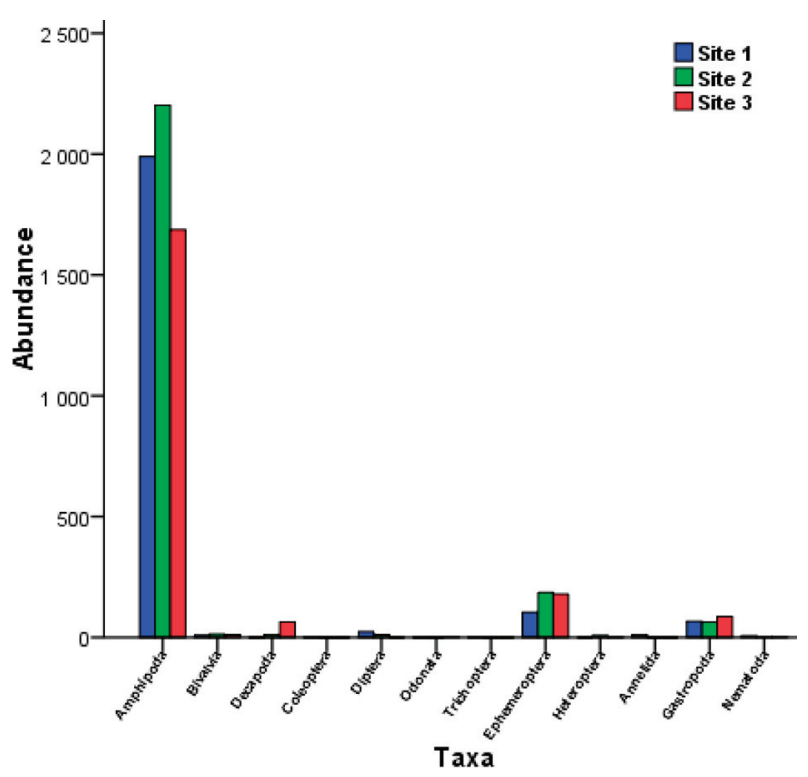

Figure 5. Abundance of macroinvertebrates at the three sites.

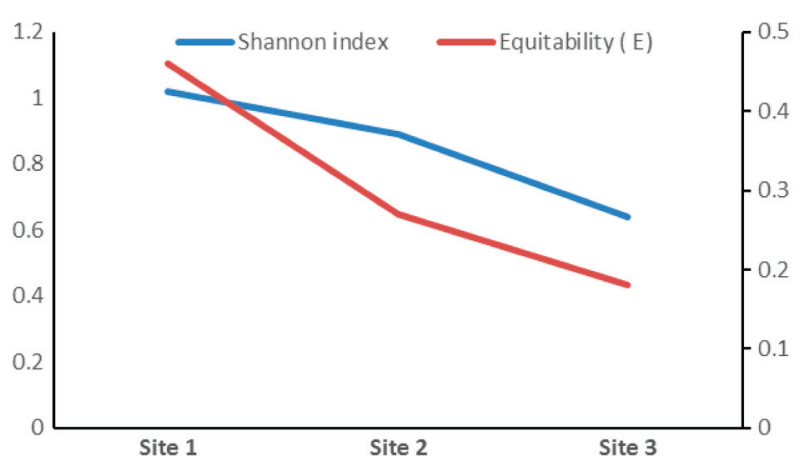

Figure 6. Spatial variation of the diversity and equitability indices of macroinvertebrates from the Bouhamdane Stream. 


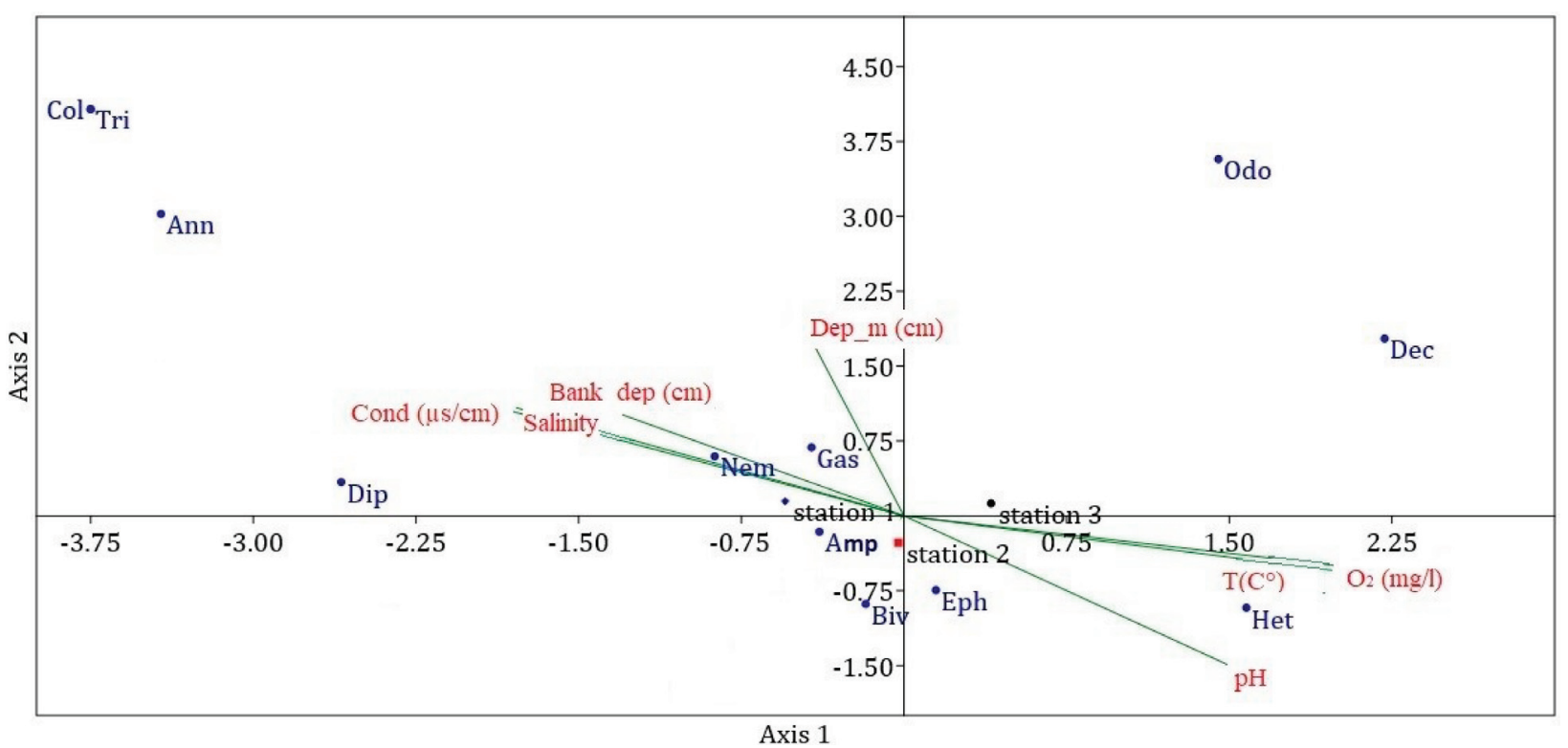

Figure 7. Canonical Correspondence Analysis (CCA) of taxa of benthic macro-invertebrates of the Bouhamdane Stream and environmental variables $\left(\mathrm{Cond}=\right.$ conductivity, $\mathrm{O} 2=$ dissolved oxygen, $\mathrm{T}\left(\mathrm{C}^{\circ}\right)=$ temperature, Salinity $=$ salinity, Dep_m $=$ depth in the middle, Bank_dep = depth of bank). Acronyms of taxa: Amp = Amphipoda, Biv = Bivalvia, Dec $=$ Decapoda, $\mathrm{Col}=$ Coleoptera, $\mathrm{Dip}=$ Diptera, Odo $=$ Odonata, $\mathrm{Tri}=$ Trichoptera, $\mathrm{Eph}=$ Ephemeroptera, Nem $=$ Nematoda, Het $=$ Heteroptera, Ann = Annelida, Gas = Gastropoda.

$\mathrm{O} 2$ and depth are the factors that most influence macroinvertebrate variation. Bivalvia, Ephemeroptera, and Heteroptera are correlated with high levels of dissolved oxygen, temperature and $\mathrm{pH}$. Amphipoda and Mollusca (Gastropoda) are positively and strongly correlated with water depth, low salinity and conductivity.

The study of macroinvertebrates from the Bouhamdane Stream (northeast of Algeria) made it possible to collect 6756 individuals belonging to 15 families and 12 orders. This richness decreases overall from upstream to downstream. Spatial (inter-site) variability in the richness of taxonomic orders was detected. It was 11 at site 1 , while 9 and 8 for sites 2 and 3, respectively. Our results reveal that the majority of macroinvertebrates in the studied environments are similar to those reported in Morocco (Giudicelli and Thiéry 1998), Italy (Bazzanti et al. 1996, 2009; Bagella et al. 2010a), Spain (Boix et al. 2004, 2008, 2009; Gascón et al. 2008,), and Algeria (Lounaci et al. 2000; Khelifa et al. 2016; Khelifa 2019; Baaloudj et al. 2020; Zouggaghe 2020).

Among the 12 orders of identified macroinvertebrates, seven were common in 3 sites, namely Amphipoda, Sphaeriida, Decapoda, Heteroptera, Ephemeroptera, Arhynchobdellida, and Hygrophila. We also noticed that crustaceans were the most represented group at all the sites (the most abundant and the most prevalent). They were followed by insects. Annelids were clearly the least observed.

The macroinvertebrate communities of the Bouhamdane Stream seem to be less diverse in comparison to other rivers, in particular those of the Kabylie Djurdjura
(Lounaci et al. 2000), Djedir and M'zistreams (Sellam et al. 2017), Boumerzoug Stream (Bekhouche et al. 2017), and Soummam Stream (Zouggaghe 2020). This could be linked to natural and/or anthropogenic factors influencing this watercourse. Indeed, the discharge of thermal waters from the Hammam Debagh spring which is not far from the study area $(27 \mathrm{~km})$ as well as domestic discharges could, without doubt, contribute considerably to the installation of adverse conditions.

Despite a high taxonomic richness of insects, the pollution-sensitive orders, Trichoptera and Coleoptera, had a low abundance. This probably reflects degradation of water quality in the study area. This same result was obtained in other studies (Zouggaghe 2003; Zouggaghe and Moali, 2009; Sellam et al. 2017). As already noted by Tachet et al. (2010), the phenomenon of the anthropization of the stream could be at the origin of the disappearance of pollution-sensitive taxa. The ephemeropteran families collected in our study are the same as the ones observed by Haouchine (2011) in the rivers of Kabylia region. This order of insects had been classified by Moisan and Pelletier (2008) as a sensitive taxon in aquatic habitats. Our study showed that crustaceans (Amphipoda) constitute the most abundant faunistic group of the fauna collected. This inequality of abundance and variable richness diversity might reflect the conditions to which the environment is subjected. Similar results were obtained in previous works (Zouggaghe and Moali 2009; Zouggaghe 2003).

For this preliminary inventory of macroinvertebrates, the observations of the groups present in the samples 
coupled with their frequency of occurrence make it possible to identify taxa that can be qualified as pollution sensitive, such as Coleoptera and Trichoptera. Our results on some taxonomic groups were similar to those reported by Zerguine and Rossaro (2010), Zebsa et al. (2014a, b), Khelifa et al. (2016), Khelifa (2019), and Baaloudj et al. (2020). In general, the obtained faunal composition in the Bouhamdane River is similar to other Algerian rivers and lakes (Meziane et al. 2020; Hassani et al. 2020).

\section{CONCLUSION}

During the present study, 6756 individuals corresponding to three faunal phyla (Arthropoda, Mollusca, Annelida) were collected. The Arthropoda phylum was the most representative in abundance and richness. Amphipod crustaceans were the dominant group (5880 individuals), followed by insects (523 individuals). Analysis of the structure of the benthic fauna of different stations reveals a poorly diversified and largely unbalanced population. Physicochemical parameters such as oxygen and depth strongly influence the distribution of benthic macroinvertebrates. The information provided here contributes to the understanding of the structure and diversity of macroinvertebrates in the Bouhamdane Stream. More detailed ecological studies would be necessary to better understand the structure and function of this ecosystem.

\section{ACKNOWLEDGMENTS}

We thank reviewers for their comments and suggestions. We are grateful to all persons who contributed to the field and laboratory analysis and finally as the general direction of scientific research and technological development (DGRSDT), Ministry of Higher Education (Algeria) for its support.

\section{Conflict of interest:}

The authors declare no conflict of interest and no financial interest.

\section{Ethics statement:}

No permission was needed to carry out our study.

\section{Author contributions:}

$\mathrm{AB}$ designed the study. $\mathrm{AB}, \mathrm{AR}, \mathrm{GM}$ and $\mathrm{SC}$ performed field and laboratory work. $\mathrm{AB}$ carried out the statistical analyses and wrote the paper. $\mathrm{AB}$ and $\mathrm{AK}$ elaborate the discussion. All authors contributed to the revision of the paper and gave final approval for publication.

\section{REFERENCES}

Afnor. 2010. Qualité écologique des milieux aquatiques. Qualité de l'eau. Traitement au laboratoire d'échantillons contenant des macro-invertébrés des cours d'eau, Association Française de Normalisation [Ecological quality of aquatic environments. Water quality. Laboratory processing of samples containing macroinvertebrates from rivers. Association Française de Normalization]. Prénorme expérimentale XP T90-333.

Alhou, B., Y. Issiaka, A. Awaiss, and J. C. Micha. 2014. Premier inventaire des macro-invertébrés du fleuve Niger à Niamey comme bioindicateurs de la pollution urbaine et industrielle. [First inventory of macroinvertebrates of River Niger in Niamey as biondicators of urban and industrial pollution]. HydroécologieAppliquée And fish second edition 18: 139-163. EPA 841-B-99-002. U.S. Environmental Protection Agency: office of water; Washington D.C.

Archaimbault, V., and B. Dumont. 2010. L'indice biologique global normalisé (IBGN): principes et évolution dans le cadre de la directive-cadre européenne sur l'eau, Sci. EauxTerrit. [The Normalized Global Biological Index (IBGN): principles and development under the European Water Framework Directive, Sci. Waters Territory]. Rev. IRSTEA 1: 36.

Armellin, A. 2010. Les communautés de macroinvertébrés benthiques: un indicateur de la qualité de l'eau au lac Saint-Pierre. [Benthic macroninvertbrate communities An indicator of ecosystem health and water quality in Lake Saint-Pierre: 8]. DOI: En84-81/2010F-PDF.

Baaloudj, A., S. Ouarab, A. Kerfouf, M. Bouriach, Ali Hussein, A. C. Hammana, and H. N'diaye Djeneba. 2020. Use of macro invertebrates to assess the quality of Seybouse River (North-East of Algeria). Ukrainian Journal of Ecology 10 (4): 60-66.

Bagella, S., M. C. Caria, and V. Zuccarello. 2010. Patterns of emblematic habitat types in Mediterranean temporary wetlands. Comptes Rendus Biologies 333: 694-700.

Barbour, M. T., J. Gerritson, B. D. Snyder, and J. B. Stribling. 1999. Rapid bioassessment protocols for use in wade able streams and rivers: periphyton, benthic macroinvertebrates. Second edition. EPA 841-B-99002. US Environmental Protection Agency; Office of Water; Washington, DC.

Bazzanti, M., and V. F. Della Bella. 2009. Functional characteristics of macroinvertebrate communities in Mediterranean ponds (Central Italy): influence of water permanence and mesohabitat type. Annales de Limnologie - International Journal of Limnology 45: 29-39.

Bazzanti, M., S. Baldoni, and M. Seminara. 1996. Invertebrate macrofauna of a temporary pond in Central Italy: composition, community parameters and temporal succession. Archiv für Hydrobiologie 137: 77-94.

Bekhouche, N., F. Marniche, and A. Ouldjaoui. 2017. 
Contribution to the study of the biodiversity of benthic invertebrates and the biological quality of some rivers in the watershed Boumerzoug (east of Algeria). Journal of Fundamental and Applied Sciences 9 (1): 234-260.

Boix, D., J. Sala, X. D. Quintana, and R. Moreno-Amich. 2004. Succession of the animal community in a Mediterranean temporary pond. Journal of North American Benthological Society 23: 29-49.

Boix, D., S. Gascón, J. Sala, A. Badosa, S. Brucet, R. LópezFlores, M. Martinoy, J. Gifre, and X. D. Quintana. 2008. Patterns of composition and species richness of crustaceans and aquatic insects along environmental gradients in Mediterranean water bodies. Hydrobiologia 597: 53-69.

Boix, D., J. Sala, S. Gascón, A. Ruhí, and X. D. Quintana. 2009. Structure of invertebrate assemblages' contribution to the ecological functioning of the Mediterranean temporary ponds. In International Conference on Mediterranean Temporary Ponds, Proceedings \& Abstracts, edited by P. Fraga, and I. Arguimbau, 153-189. Maó, Menorca, Spain: Consell Insular de Menorca, Recerca, 14.

Boix, D., E. García-Berthou, S. Gascón, L. Benejam, E. Tornés, J. Sala, J. Benito, A. Munné, C. Solà, and S. Sabater. 2010. Response of community structure to sustained drought in Mediterranean rivers. Journal of Hydrology 383: 135-146.

Bournaud, M., G. Keck, and P. Richoux. 1980. Les prélèvements de macroinvertébrés benthiques en tant que révélateurs de la physionomie d'une rivière. [Macroinvertebrate samples and how they reveal the physionomy of a river]. Annales de limnologie 16 (1): 55-75. Site Biologique du lac d'Orédon. DOI: http:// dx.doi.org/10.1051/limn/1980009

Camargo, J. A., A. Alonso, and M. De La Puente. 2004. Multimetric assessment of nutrient enrichment in impounded rivers based on benthic macroinvertebrates. Environmental Monitoring and Assessment 96 : 233-249.

Chessman, B. C. 1995. Rapid assessment of rivers using macroinvertebrates: A procedure based on habitatspecific sampling, family level identification and biotic index. Australian journal of ecology 20: 122-129.

Dajoz, R. 2006. Précis d'écologie. Dunod: 640 pp.

Dudgeon, D., A. H. Arthington, M. O. Gessner, Z. I. Kawabata, D. J. Knowler, C. Lévêque, R. J. Naiman, A. H. Prieur-Richard, D. Soto, and M. L. Stiassny. 2006. Freshwater biodiversity: importance, threats, status and conservation challenges. Biological Reviews 81: 163-182.

Engelhardt, W. 1998. Guide vigot de la vie dans les étangs, les ruisseaux et les mares. [Vigot guide of life in ponds, streams and pools]. Vigot France, 313 pp.

Ferguani, H., and A. Arab. 2013. Utilisation des macroinvertébrés benthiques comme bioindicateurs de pollution
d'Oued El Harrach. [Use of macroinvertebrates as bioindicators of water pollution in El Harrach Stream]. 4éme Congrès International des Populations et des Communautés Animales Taghit, Algérie. Communications internationales: 205-212.

Fleurant, C. 2016. Les zones humides: fonctions, services et enjeux. Journées Mondiales des Zones Humides. Département de Géographie UMR 6554 CNRS LETG Angers.

Fustec, É., and J. C. Lefeuvre. 2000. Fonctions et valeurs des zones humides. [Functions and values of wetlands]. Paris: Dunod, 426 pp.

García, N., A. Cuttelod, and D. A. Malak. 2010. The status and distribution of freshwater biodiversity in Northern Africa. The IUCN Red List of threatened species, $141 \mathrm{pp}$.

Gascon S., D. Boix, J. Sala, and X. D. Quintana. 2008. Relation between macroinvertebrate life strategies and habitat traits in Mediterranean salt marsh ponds (Emporda' wetlands, NE Iberian Peninsula). Hydrobiologia 597: 71-83.

Giudicelli, J., and A. Thiéry. 1998. La faune des mares temporaires, son originalité et son intérêt pour la biodiversité des eaux continental esméditerranéennes. [The fauna of temporary pools, its originality and its values for the biodiversity of continental Mediterranean waters]. Ecologia Mediterranea 24 (2): 135-143.

Giudicelli, J., M. Dakki, and A. Dia. 1985. Caractéristiques abiotiques et hydrobiologiques des eaux courantes méditerranéennes: Avec 1 figure et 1 tableau dans le texte. [Abiotic and hydrobiological characteristics of Mediteranean running water: with 1 figure and 1 table in the text]. Internationale Vereinigung für theoretische und angewandte Limnologie: Verhandlungen 22 (4): 2094-2101.

Hammer, Ø., D. A. T. Harper, and P. D. Ryan. 2001. PAST: Paleontological statistics software package for education and data analysis. Palaeontologia Electronica 4: 9.

Haouchine, S. 2011. Recherches sur la faunistique et l'écologie des macroinvertébrés descours d'eau de Kabylie. Thèse de doctorat. [Research on the Faunistic quality and the ecology of benthic macroinvertebrates of Kabylie Rivers. Doctoral thesis. Tizi Ouzou Univ.]. Université Mouloud Maameri de Tizi Ouzou, Algérie.

Hassani, M. M., A. Kerfouf, A. Baaloudj, and F. Denis. 2020. Parasite diversity from two deep-sea fishes Phycis blennoides (Brûnnich, 1768) and Phycis phycis (Linné, 1758), from the western Algerian coasts. Ukrainian Journal of Ecology 10 (3): 86-92.

Khelifa, R. 2019. Sensitivity of biodiversity indices to life history stage, habitat type and landscape in Odonata community. Biological Conservation 237: 63-69.

Khelifa, R., R. Zebsa, H. Amari, M. K. Mellal, H. Mahdjoub, and A. Kahalerras. 2016. A hot spot for threatened Mediterranean odonates in the Seybouse River (North- 
east Algeria): are IUCN population sizes drastically underestimated? International Journal of Odonatology 19: 1-11. DOI: org/10.1080/13887890.2015.1133331

Leraut, P. 2007. Ébauche d'une liste des pyrales de France (Lepidoptera, Pyraloidea). [Preliminary list of pyralids moths from France (Lepidoptera, Pyraloidea)]. Revue française d'entomologie 29 (4): 149-166.

Lounaci, A., S. Brosse, A. Thomas, and S. Lek. 2000. Abundance, diversity and community structure of macroinvertebrates in an Algerian stream: the Sébaou stream. Annals of Limnology 36 (2): 123-133.

Meziane, K., K. Kerfouf, and A. Baaloudj. 2020. Checklist of gastropod molluscs in west coast of Algeria. Revue International Journal of Aquatic Biology (IJAB) 8 (3): 224-227.

Moisan, J. 2010. Guide d'identification des principaux macroinvertébrés benthiques d'eau douce du Québec, 2010: Surveillance volontaire des cours d'eau peu profonds. Direction du suivi de l'état de l'environnement, ministère du Développement durable, environnement et parcs Québec.

Moisan, J., and L. Pelletier. 2008. Guide de surveillance biologique basée sur lesmacroinverté-brés benthiques d'eau douce du Québec - Cours d'eau peu profonds à substrat grossier. [Biological monitoring guide based on benthic fresh water macroinvertebrates from Quebec-Shallow rivers with coarse substrate]. Direction du suivi de l'état de l'environnement, ministère du Développement durable de 1'Environnement et des Parcs, Québec, Canada, 86 pp.

Ramade, F., L. Lagadic, and T. Caquet. 1994. The role of biomarkers in environmental assessment (5). Invertebrate populations and communities. Ecotoxicology 3 (3): 193-208.

R Development Core Team. 2019. R: A Language and Environment for Statistical Computing. Vienna, Austria. R Foundation for Statistical Computing.

Sanogo, S., J. A. T. Kabre, and P. Cecchi. 2014. Inventaire et distribution spatio-temporelle des macroinvertébrés bioindicateurs de trois plans d'eau du bassin de la Volta au Burkina Faso. [Spatio-temporal inventory and distribution of bioindicator macroinventebrates from three ponds water of Volta, Burkina Faso]. International Journal of Biological and Chemical Sciences 8
(3): 1005-1029. DOI: http://dx.doi.org/10.4314/ijbcs. v8i3.16

Sellam, N., F. Zouggaghe, B. Alloul, A. Mimouni, and R. Moulaï. 2017. Taxa richness and community structure of macroinvertebrates in rivers of different bioclimatic regions of Algeria. Journal of Materials and Environmental Sciences 8: 1574-1588.

Tachet, H., P. Richoux, M. Bournaud, and P. Usseglio-Polatera. 2010. Invertébrés d'eau douce: systématique, biologie, écologie. [Freshwater invertebrates: systematic, biology, ecology]: 15. Paris: CNRS.

Tachet, H., P. Richoux, M. Bournaud, and P. UsseglioPolatera. 2013. Invertébrés d'eau douce: systématique, biologie, écologie. [Freshwater invertebrates: systematic, biology, ecology]: 15. Paris: CNRS.

Véronique, B. C. 2014. Les facteurs de sélection des bio-indicateurs de la qualité des écosystèmes aquatiques: Elaboration d'un outil d'aide à la décision. [The factors for selecting bio-indicators of the quality of aquatic ecosystems: Development of a decision-support tool]. Mémoire de maitrise: 118 pp. Université de Sherebrooke.

Zebsa, R., R. Khelifa, A. Kahalerras, H. Djalal, and M. Houhamdi. 2014a. Emergence pattern, site selection, and seasonal regulation of Onychogomphus costae Selys, 1885 (Odonata: Gomphidae) in northeastern Algeria. Aquatic Insects 36: 257-265.

Zebsa, R., R. Khelifa, and A. Kahalerras. 2014b. Emergence pattern, microhabitat choice, and population structure of the Maghribian endemic Gomphus lucasii Selys, 1849 (Odonata: Gomphidae) in northeastern Algeria. Aquatic Insects 36: 245-255.

Zerguine, K., and B. Rossaro. 2010. A new species of Hydrobaenus Fries, 1830 (Diptera, Chironomidae) from Algeria. Zootaxa 2507: 37-43.

Zouggaghe, F. 2003. Mémoire de Magister en biologie [Magister's thesis in biology] Université Abderrahmane Mira de Béjaia, 74 pp.

Zouggaghe, F. 2020. Structure et distribution des macro-invertébrés aquatiques e la kabyliede la Soummam (nord de l'Algérie). Bull. soc. zool. fr. 145 (3): 295-310.

Zouggaghe F., and A. Moali. 2009. Variabilité structurelle des peuplements de macro-invertébrés benthiques dans le bassin versant de la Soummam (Algérie, Afrique du Nord). Revue D'Ecologie-La Terre et La Vie 64 (4): 305. 